\title{
Impact of Selected Architectural Concrete Modifications on Mechanical Parameters and Durability
}

\author{
Martin Tazky, Lucia Osuska, Petr Novosad, and Rudolf Hela
}

\begin{abstract}
Concrete is a composite material for which a wide range of special modification possibilities are possible in both a fresh and hardened state, which provides a number of options for using concrete in architecture, as well as interior and exterior design. This article deals with the possibility of colouring a concrete mixture and the subsequent modification of hardened concrete, such as washed and polished concrete surfaces. The objective of the article is to verify the impact of these modifications on the production of concrete itself, and subsequently, on the physical-mechanical parameters and durability that determine the area for which this architectural concrete can be used (urban furniture, garden furniture, fence elements, interior design, etc.).
\end{abstract}

Index Terms-Architectural concrete, design, durability, polished surface, washed surface, pigment.

\section{INTRODUCTION}

Architectural concrete is a material used in modern architecture. Due to the development of chemical additives and cosmetic additives, the visual properties of the concrete surface can be easily changed. For a larger range of non-natural concrete colors, pigments are used [1]. Pigments are substances that have a dye in a suitable environment (for example, an alkaline environment for fresh concrete). Concrete can be produced with a pigment in different color shades, with a number of possible additional surface modifications by designer, architect and investor [2].

For the use of pigments in fresh concrete or when treating a hardened concrete surface, it is necessary to determine the suitability of these modifications in terms of mechanical and durable parameters of concrete, whether concrete should fulfill a static function, and if exposed to aggressive environments or climatic impacts [3].

This paper deals with the possibility of producing colored concrete using a powder pigment and subsequent surface treatment. Within the realized experiment, the impact of the concrete paint was monitored on concrete production itself; two surface modifications were subsequently made to determine their effect on the durability parameters. The first

Manuscript received May 5, 2018; revised August 23, 2018. This work was supported in part by the Brno University of Technology department of Civil Engineering, Institute of Technology of Buildings Materials and Components. Theoretical background for the presented results was obtained with financial support of the project FAST-J-18-5367, "Impact of SNCR on the quality of high-temperature fly ash for use as an additive to cement composites".

The authors are with the Brno University of Technology department of Civil Engineering, Institute of technology of Buildings Materials and Components, Veveri 331/95, 60200 Brno, Czech Republic (e-mail: tazky.m@fce.vutbr.cz, osuska.1@fce.vutbr.cz, novosad.p@fce.vutbr.cz,: hela.r@fce.vutbr.cz). surface modification was the aggregate grain exposure by slowing down and then washing the surface layer of the cement sealant. The second surface modification was the exposure of aggregate grains to grinding and subsequent polishing of the surface of the concrete. The aim of the experiment was to assess the suitability of surface treatments for colored concrete for its external use when exposed to different types of stress due to aggressive impacts.

\section{EXPERIMENT}

\section{A. Colouring the Concrete Matrix}

Different colour shades for concrete elements can be achieved using pigments. Pigments for concrete are generally either organic or inorganic. Their use and selection are primarily determined by the desired degree of colouring, shade, and conditions to which the concrete will be exposed. Their dosing is always realised during the production of the concrete mixture, and the exact amount is given according to the desired shade of the concrete, which also depends on the input of raw materials. To improve the colouring ability of the pigment used, suitable additives are often used, for example, finely ground slag or limestone. For extremely bright shades of concrete, white cement must be used. Using white cement and quality aggregate, which is entirely free from impurities, it is possible to produce white concrete.

Three concrete mixtures of the same composition were produced for the experiment. One mixture was left entirely without colouring as a reference mixture, and the other two were used to simulate the production of coloured concrete. The first colouring method was performed using white cement. In the second case, a powder black pigment was added to the concrete. The concrete composition of individual recipes is shown in Table I.

TABLE I: COMPOSITION OF CONCRETE MIXTURES

\begin{tabular}{lccc}
\hline \hline Raw materials & REF & $\begin{array}{l}\text { White } \\
\text { concrete }\end{array}$ & $\begin{array}{l}\text { Black } \\
\text { concrete }\end{array}$ \\
\hline CEM I 42.5 R [kg] & 380 & - & 380 \\
CEM I 52.5 R white [kg] & - & 380 & - \\
Slag [kg] & 50 & 50 & 50 \\
w/b [-] & 0.40 & 0.40 & 0.41 \\
Aggregate 0-4 mm [\%] & & 48 & \\
Aggregate 4-8 mm [\%] & & 23 & \\
Aggregate 8-16 mm [\%] & & 29 & \\
Plasticizer [\%] & 1.0 & 1.0 & 1.1 \\
Black pigment [kg] & - & - & 19 \\
\hline \hline
\end{tabular}

For all recipes, in order to observe the equation of absolute volumes and depending on the different densities of both 
cements and pigment, correction was realised only according to aggregate dose.

The black pigment was a ferric black inorganic pigment in powder form (supplied by Precheza a.s).

The concrete mixtures were made to consistency grade S3, according to EN 12350-2Nenalezen zdroj odkazů. In addition, to determine the impact of both methods for colouring fresh concrete, the fresh concrete air content was determined in accordance with EN 12350-7Chyba! Nenalezen zdroj odkazů. The results of all fresh concrete tests carried out are presented in Table II.

TABLE II: COMPOSITION OF CONCRETE PICTURES

\begin{tabular}{lccc}
\hline \hline Parameters & REF & $\begin{array}{l}\text { White } \\
\text { concrete }\end{array}$ & $\begin{array}{l}\text { Black } \\
\text { concrete }\end{array}$ \\
\hline Slump-test $[\mathrm{mm}]$ & 160 & 160 & 150 \\
Temperature FC $\left[{ }^{\circ} \mathrm{C}\right]$ & 22.2 & 22.6 & 22.2 \\
Air content in FC $[\%]$ & 2.2 & 3.0 & 2.1 \\
Density FC $\left[\mathrm{kg} \cdot \mathrm{m}^{-3}\right]$ & 2360 & 2380 & 2370 \\
\hline \hline
\end{tabular}

From the results of consistency determination by the slump-test, and from the dose correction of the mixing water and the super-plasticiser admixture, it is obvious that by adding the pigment powder used, the concrete mixture became more demanding for water, due to the highly specific surface of this pigment. This claim, however, may not be generally applicable to all types of pigment; this potentially negative effect can be eliminated by using liquid pigments.

The results of air content determination in fresh concrete points to a slight negative effect of air pores formation when using white cement. These air pores are undesirable, particularly due to a decrease in mechanical parameters of hardened concrete. Their positive influence on durability parameters cannot be assumed, because they are not effective micropores, which are deliberately created by using special aeration additives for increasing concrete durability in frost environments.

\section{B. Impact of Colouring on Frost Resistance}

If the concrete is to be exposed to outdoor conditions in areas where frost occurs, it is necessary to be so-called 'frost resistant'. This property was determined on all produced concrete according to the standard procedure ČSN 73 1322[6], which consists of cyclic rotation at $-20^{\circ} \mathrm{C}$ and watering of samples at $20^{\circ} \mathrm{C}$. Joists with dimensions of $100 \mathrm{x}$ $100 \times 400 \mathrm{~mm}$ were used as test specimens which, after performing the required number of freezing cycles, were tested for concrete tensile strength in bending according to EN 12390-5[7], and fragments were used for the determination of the compressive strength of concrete according to EN 12390-3[8]. In the same way, comparative samples made from the same concrete mixture were tested and the results of the individual tests were compared. Concrete is considered to be frost resistant if tensile strength in bending of the frozen samples was maximally $75 \%$ (frost resistance index 0.75), compared to the strength of the comparative samples.

Large sections of exterior architectural concrete are exposed to climatic influence; the frost resistance of concrete can therefore be a decisive parameter in terms of maintaining the desired permanent appearance. For coloured concrete, its frost resistance may be affected by the use of a pigment. In addition, such concrete can gradually lose its colour stability when exposed to frost.

The following table shows the achieved results of the above described tests.

TABLE III: RESULTS OF FRONT RESISTANCE

\begin{tabular}{lccc}
\hline \hline Parameters & REF & $\begin{array}{l}\text { White } \\
\text { concrete }\end{array}$ & $\begin{array}{l}\text { Black } \\
\text { concrete }\end{array}$ \\
\hline $\begin{array}{l}\text { Weight chance after 100 } \\
\text { cycles [\%] }\end{array}$ & -0.14 & -0.14 & -0.18 \\
$\begin{array}{l}\text { Front resistance index } \\
\text { after 100 cycles - } \\
\text { compressive [-] }\end{array}$ & 1.00 & 1.14 & 0.97 \\
$\begin{array}{l}\text { Front resistance index } \\
\text { after 100 cycles - } \\
\text { bending [-] }\end{array}$ & 1.16 & 1.15 & 1.06 \\
\hline \hline
\end{tabular}

The results of frost resistance show that all produced concrete, respectively, concrete with white cement and concrete with the addition of black pigment, were well resistant to frost after 100 freezing cycles. Neither the pigment used nor the white cement showed a negative impact on frost resistance for the coloured concrete. As shown in Figure 1, in visual terms, 100 cycles of frost resistance did not result in a loss of colour. In the photo for illustration, only concrete with black pigment is displayed, on the photography is the fracture area of the reference and the frozen sample.

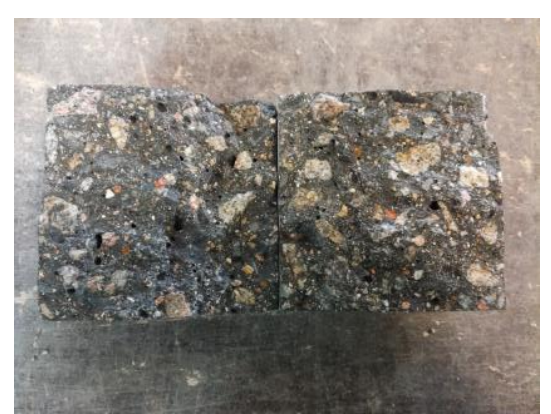

Fig. 1. The fracture area of concrete, coloured with black pigment (on the left is a comparative sample, while the right image shows results after 100 freezing cycles).

\section{Selected Surface Modification of Architectural Concrete}

Two approaches for the surface modification of concrete were selected in the experiment. The first modification was exposure of the aggregate grains using hydration retardation, then washing out the surface layer of the cement putty. Two procedures can generally be used to do this. The first is to apply the retardant to the surface of the concrete immediately after its production, for example, by spraying. The second option is to use so-called 'deceleration papers', which are impregnated with a retardant and stored in the mould. Subsequently, a concrete mixture is poured onto the papers. In the case discussed here, a greater possibility of individuality in the creation of the graphic design is provided by the washing-out method.

In this experiment, the first procedure was used, in which a retardant was applied on the surface of samples by spraying, immediately after the production of the concrete mixture and the production of test specimens. Approximately 12 hours 
later, these surfaces were washed out with a stream of water, as shown in Fig. 2. This procedure produced test samples with the required dimensions for the washed out surface of the concrete and with exposed stone.

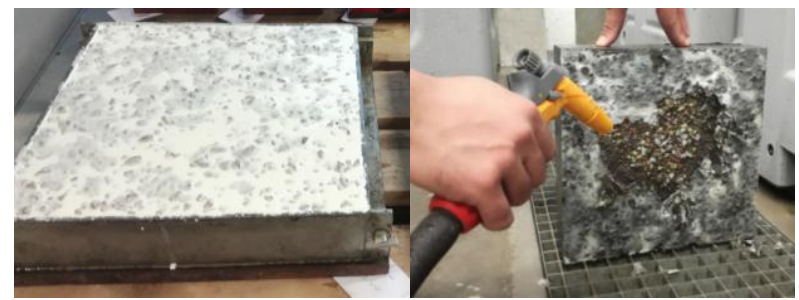

Fig. 2. The surface of the test specimens with the retardant-applied sample and the washed-out sample.

The second used surface modification of hardened concrete was its grinding and subsequent polishing. This modification is commonly used where an effort is made to expose the aggregate used; a concrete matrix is made and conditions are set for surface smoothness. Examples include the lining elements or floor coverings.

The resulting difference in surfaces using the same concrete is shown in Fig. 3. Samples are shown that were used to determine the resistance of these surfaces to frost and chemical defrosting substances. The objective of the experiment was to verify the impact of coloured concrete surface modification and its resistance to an aggressive environment.

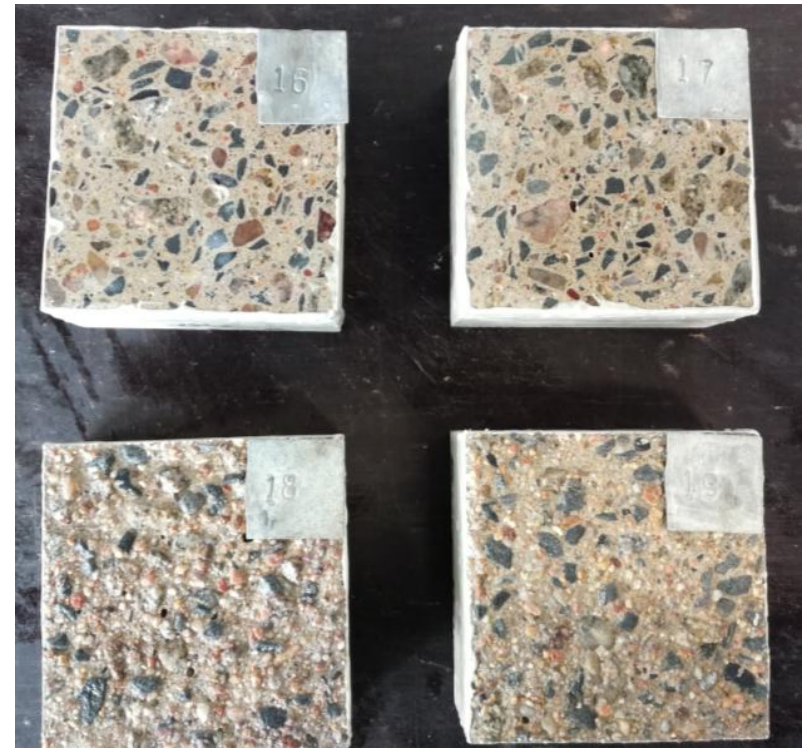

Fig. 3. White concrete: different surface modifications (top is polished; bottom is washed-out).

Good surface resistance of concrete elements against frost and chemical defrosting substances is required when the samples are exposed to an outdoor environment where frost and the application of road salt can be expected. This resistance is therefore essential, particularly for samples used as floor coverings or as lining elements near roads, where there is a risk of contact with aggressive media. During the test, the modified surface sides of samples were immersed to a height of $5 \mathrm{~mm}$ in a $3 \% \mathrm{NaCl}$ solution, and subjected to cyclic frost and heat rotation. The results of the test, realised according to the standard procedure ČSN 731326 Chyba!
Nenalezen zdroj odkazů. are shown in the following tables. A satisfactory result is considered the maximum waste rate after 100 freezing cycles of $1000 \mathrm{~g} / \mathrm{m}^{2}$.

TABLE IV: RESUlts of SURFACE RESISTANCE TO FROST AND CHEMICAL DEFROSTING SUBSTANCES - REF

\begin{tabular}{lcc}
\hline \hline Parameters & REF-washed out & REF-polished \\
\hline $\begin{array}{l}\text { Waste after } 25 \text { cycles } \\
{\left[\mathrm{g} / \mathrm{m}^{2}\right]}\end{array}$ & 324.4 & 51.0 \\
$\begin{array}{l}\text { Waste after } 50 \text { cycles } \\
{\left[\mathrm{g} / \mathrm{m}^{2}\right]-\text { totalised }}\end{array}$ & 538.7 & 118.7 \\
$\begin{array}{l}\text { Waste after } 100 \text { cycles } \\
{\left[\mathrm{g} / \mathrm{m}^{2}\right]-\text { totalised }}\end{array}$ & 701.4 & 205.8 \\
$\begin{array}{l}\text { Waste after } 150 \text { cycles } \\
{\left[\mathrm{g} / \mathrm{m}^{2}\right]-\text { totalised }}\end{array}$ & 850.6 & 371.3 \\
\hline \hline
\end{tabular}

TABLE V: RESUltS OF SURFACE RESISTANCE TO FROST AND CHEMICAL DEFROSTING SUBSTANCES - WHITE CONCRETE

\begin{tabular}{lcc}
\hline \hline Parameters & $\begin{array}{l}\text { White } \\
\text { concrete-washed out }\end{array}$ & $\begin{array}{l}\text { White } \\
\text { concrete-polished }\end{array}$ \\
\hline $\begin{array}{l}\text { Waste after 25 cycles } \\
{\left[\mathrm{g} / \mathrm{m}^{2}\right]}\end{array}$ & 269.7 & 47.4 \\
$\begin{array}{l}\text { Waste after } 50 \text { cycles } \\
{\left[\mathrm{g} / \mathrm{m}^{2}\right]-\text { totalised }}\end{array}$ & 420.1 & 144.2 \\
$\begin{array}{l}\text { Waste after } 100 \text { cycles } \\
{\left[\mathrm{g} / \mathrm{m}^{2}\right]-\text { totalised }}\end{array}$ & 539.4 & 280.7 \\
$\begin{array}{l}\text { Waste after } 150 \text { cycles } \\
{\left[\mathrm{g} / \mathrm{m}^{2}\right]-\text { totalised }}\end{array}$ & 695.2 & 488.3 \\
\hline \hline
\end{tabular}

TABLE VI: RESULTS OF SURFACE RESISTANCE TO FROST AND CHEMICAL DEFROSTING SUBSTANCES - BLACK CONCRETE

\begin{tabular}{lcc}
\hline \hline Parameters & $\begin{array}{l}\text { Black } \\
\text { concrete-washed out }\end{array}$ & $\begin{array}{l}\text { Black } \\
\text { concrete-polished }\end{array}$ \\
\hline $\begin{array}{l}\text { Waste after 25 cycles } \\
{\left[\mathrm{g} / \mathrm{m}^{2}\right]}\end{array}$ & 492.0 & 109.7 \\
$\begin{array}{l}\text { Waste after 50 cycles } \\
{\left[\mathrm{g} / \mathrm{m}^{2}\right]-\text { totalised }}\end{array}$ & 949.0 & 260.8 \\
$\begin{array}{l}\text { Waste after 100 cycles } \\
{\left[\mathrm{g} / \mathrm{m}^{2}\right]-\text { totalised }} \\
\text { Waste after 150 cycles } \\
{\left[\mathrm{g} / \mathrm{m}^{2}\right]-\text { totalised }}\end{array}$ & 1369.4 & 445.0 \\
\hline \hline
\end{tabular}

The results of the tests clearly demonstrate the difference in the resistance of the washed-out and polished surfaces. Although in most samples, both types of surface were suitable for this test, there were significant differences between the resistance of all polished and washed-out surfaces. Washed-out surfaces were more prone to the retention of frozen fluid on a granular surface, which resulted in reduced resistance to this type of aggressive environment. Contrarily, the completely smooth surfaces resisted the aggressive environment, because the aggressive medium did not have the ability to adhere to them.

Significant differences were also observed for the coloured concrete. Colouring the concrete matrix only with white cement had no significant impact on frost resistance or resistance to chemical defrosting substances. Conversely, the concrete for which colouring the black pigment was used had noticeably impaired durability, and in the case of the washed out surface, the samples indicated an entirely unsatisfactory resistance value.

In this experiment, the strong effect of the pigment on the surface's resistance to freezing effects, and to the effects of chemical defrosting substances was proven; however, its use appears problematic. It was also demonstrated that for the 
application of architectural concrete elements, which will be heavily stressed by frost and defrosting substances, such surface modifications are suitable, and will ensure that aggressive media will not be able to adhere to the concrete's surface.

\section{CONCLUSION}

In the production of architectural concrete, there are many ways to modify its colour and surface visibility. However, achieving the desired colour or the desired surface modification is not entirely without limitations, including a possible reduction in durability when used outside. Prior to each production of a special concrete element with a unique design, it is necessary to carefully consider the environment in which this element or construction will be placed. Even a completely unique architectural concrete cannot preserve its originality unless it is able to resist the aggressiveness of the environment in which it is located. Some types of pigments that are used to achieve the desired colour of the cement matrix may impair the durability of concrete in an outdoor environment. It is necessary to remember that each additional modification of the surface of architectural concrete must be selected by also considering the use of said concrete, and the durability aspects of the concrete in the chosen environment.

\section{REFERENCES}

[1] D. Bennett, "Architectural institute of concrete," London: RIBA Pub, 2007.
[2] F. Seidel, Architecture Materials: Concrete bÉton, Beton. Köln Evergreen, 2008.

[3] J. Fischer, Concrete: Beton, Potsdam: H. F. Ullmann, pp 172-175, 2008.

[4] EN 12350-2, Testing fresh concrete - Part 2: Slump-test, 2009.

[5] EN 12350-7, Testing fresh concrete - Part 7: Air content - Pressure methods, 2009.

[6] In Czech: ČSN 73 1322. Stanovení mrazuvzdornosti betonu, ÚNMZ, Praha, 1969

[7] EN 12390-5, Testing hardened concrete - Part 5: Flexural strength of test specimens, 2009.

[8] EN 12390-3, Testing hardened concrete - Part 3: Compressive strength of test specimens, 2009.

[9] In Czech: ČSN 73 1326. Stanovení odolnosti povrchu cementového betonu proti působení vody a chemických rozmrazovacích látek, ÚNMZ, Praha, 1985

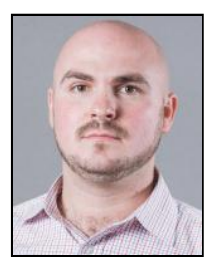

Martin Tazky was born in Strernberk, Moravian region Czech Republic on $10^{\text {th }}$ of January 1990. In 2016 he graduated Brno University of Technology, Civil engineering - Institute of Technology and Buildings Materials and Composites and he get a title Ing. At the present time he continues a study as an Ph.D. candidate. During his study he was participate of an internship in CEMEX Reserch Group in Switzerland, were he worked as a researcher. At the present time he works at AdMas Center (Advanced Materials, Structures and Technologies Institute https://admas.eu/en/) as an researcher. He published at many domestic and foreign conference indexed by SCOPUS and other important periodic. His background is technology of concrete and silicates composites. His specialization is the use of secondary raw materials and the development of special concrete.

Mr. Ing. Martin Ťažký finished his study with excellent results and his final theses were appreciated in nationwide competition Czech Concrete Society in 2014 and 2016 